\title{
Implementation Evaluation in Paralympic Sports Achievement Development
}

\author{
Kevin Fabiano \\ Postgraduate in Sports Science, Sebelas Maret University, Indonesia \\ Corresponding author email: kevinfabiano64@gmail.com \\ M. Furqon Hidayatullah \\ Postgraduate in Sports Science, Sebelas Maret University, Indonesia \\ Email: furqon@uns.ac.id \\ Sapta Kunta Purnama \\ Postgraduate in Sports Science, Sebelas Maret University, Indonesia \\ Email: saptakunta_p@yahoo.com
}

\begin{abstract}
This study aims to determine the implementation of Paralympic sports achievement coaching which is carried out independently in the preparation for Peparnas Papua in 2021. This research is an evaluative study with the Context, Input, Process, Product (CIPP) model. The data analysis technique used in this research is descriptive analysis. The results showed that the West Java NPCI athletes had a fairly good quality. Trainers at NPCI West Java have qualifications as licensed trainers. The organization of the West Java NPCI has been carried out quite well. The facilities and infrastructure in supporting the implementation of the NPCI West Java platda have quite good criteria. The funding of the West Java NPCI platda has been included in the category good enough for athletes and coaches and intensive bonuses for athletes and coaches. The selection of West Java NPCI athletes has been carried out quite well. The West Java NPCI training program is currently carried out quite well through the suitability of the planning program with the implementation and suitability of independent training. The evaluation of the West Java NPCI platda is carried out by the trainer at the end or after each exercise and runs smoothly.

Keywords---achievement development, evaluation, paralympic sports, platda, product.
\end{abstract}

\section{Introduction}

The West Java National Paralympic Committee (NPCI) ensures the regional training center (Pelatda) program to face the 2021 National Paralympic Week (Peparnas) in Papua. The West Java National Paralympic Committee Indonesia (NPCI) maps the athletes in January 2021. West Java Province as the winner of the overall title of Peparnas XV/ 2016 must prepare extra hard. In 2016, the West Java NPCI managed to become the overall champion as the host. The Indonesian National Paralympic Committee (Pelatda NPCI) West Java with 200 regional athletes plus 58 national athletes, West Java NPCI is aiming for 100 gold medals to defend the overall title at the XVI/ 2021 National Paralympic Week (Peparnas) in Papua (Kliwon \& Sarwanto, 2019). This regional training program is implemented in seven cities/districts, namely Kuningan Regency, Garut Regency, Tasikmalaya City, Bogor Regency, Bandung City / Regency, and Cirebon City.

Athletics is one of the elements of physical and health education, as well as components of overall education that prioritizes physical activity as well as fostering a healthy life and physical development, mentally, socially, and emotionally that is harmonious, harmonious, and also balanced (Wijayanti et al., 2016). Athletics is a sport consisting of running numbers, jumping numbers, and throwing numbers (Kardiyanto, 2017). The numbers mentioned above consist of various kinds of events including running numbers, which consist of: short distance running events, medium distance running, long-distance running, and marathon running (Budi \& Lismadiana, 2020). 
Meanwhile, the jump numbers consist of: multiple jumps, high jump, pole jump, and long jump (Rahmat, 2015). The throwing numbers consist of: discus throwing, bullet throwing, javelin throwing, and hammer throwing (Imanudin, 2011). These events usually compete in various competitions, both at the regional, provincial, national, and international levels. Also, athletics is a mandatory sport in multi-event championships, including: POPDA, O2SN, POPNAS, PORPROV/ PORDA, PON, as well as ASEAN GAMES, SEA GAMES, Olympics, and others (Zuhriyah et al., 2020). This very diverse championship is held to find and channel athletic talents, especially athletic talents (Pullen \& Silk, 2020). Multi-event championships for junior high and high school students include the O2SN and POPNAS championships, while the multi-event championships for the public are PON (Batistuta \& Supriyono, 2019a).

Along with the increasing number and variety of events held to channel athletic talents, competitions for people with special needs/ disabilities also exist both on the national and international levels (Hendri \& Supriyono, 2019b). One of the national level events for people with disabilities is PEPARNAS, which is currently being held simultaneously after PON (Putra \& Ita, 2019). PEPARNAS (National Paralympic Week) is a multi-event championship specifically for athletes with disabilities. The event for athletes with special needs proves that people with disabilities are also able to optimize their abilities to compete in the world of sports, especially competitive sports (Dieffenbach \& Statler, 2012; Singh \& Parmar, 2016).

Given that athletics is a multi-event sport with various sports numbers (Nakamura et al., 2018). The number of sports that are usually contested in PEPARNAS events, namely; running number, long jump, double jump, javelin, throwing disc, high jump, and shot put. In the running numbers, including wheelchair class, in addition to the 100, 200 , and $400 \mathrm{~m}$ sprints, there are also competitions for medium-distance runs of 800 and 1,500 $\mathrm{m}$, and long distances of 5,000 and 10,000 m. Another number is the relay race $4 \times 100 \mathrm{~m}$. Athletes are divided into four types of disabilities, namely the blind, mentally disabled, amputee, and deaf, competing in several athletic sports, which are adjusted according to the athlete's disability (Ona Ayala et al., 2019). This is related to the shortcomings that each athlete with disabilities has. In national-level competitions/events such as PEPARNAS, it is an event to show athletes' abilities and as a measure of ability at the next level event (Jaarsma et al., 2014). Athletes who have good record limits or disabilities will certainly participate in competitions at the international level, such as the ASEAN Paralympic Games (Brittain, 2012).

However, many of our people do not yet understand and accept that Paralympians can excel in sports because of their limitations. With the many special championships for people with disabilities both on the national and international level, it proves that Paralympians can excel at national and international disability sports and this proves that Paralympian sports are starting to develop in Indonesia. Many records were broken in the event, but there were also many obstacles faced by athletes and management. One of the obstacles faced in this sports coaching is the infrastructure aimed at the Paralympians, which are not yet widely available. Coaching is the main elements that must be done to achieve high achievement. However, it needs support from various elements. This is because high achievement is not only through a good coaching process, but needs support from various elements including a healthy organization, good management, proper training programs, good facilities, and infrastructure, as well as support from the government and the community.

Organizational, management, guidance, infrastructure and facilities, and a good training program are elements that cannot be separated in the development of sports achievements. These elements are related to one another. If these elements are in good condition, sports coaching activities can run smoothly so that high achievements can be achieved. On the other hand, if these elements are in an unhealthy or unstable condition, sports activities cannot run as expected and maximum achievement cannot be achieved.

To find out the extent of coaching and aspects that have not received attention in the achievement of paralympic sports, especially in the athletic sport, it is necessary to research by extracting information from the elements that support the development of this achievement sport (Blauwet \& Willick, 2012; Beckman et al., 2017). Extracting information, training programs, facilities, and infrastructure, as well as guidance.

\section{Methods}

This research is an evaluative study with a context, input, process, product (CIPP) model. The sampling technique used in this study was the purposive sampling technique. Data collection techniques in this evaluative research are observation and questionnaires. The method used in this research is a questionnaire method using a Likert scale. The data analysis technique used in this research is descriptive analysis, namely by describing and interpreting the data from each of the components being evaluated. 
Results and Discussion

Table 1

Descriptive statistical evaluation of the implementation of independent paralympic sports achievement coaching in preparation Peparnas Papua in 2021

\begin{tabular}{lcccccccc}
\hline & Athlete & Trainer & Organizing & $\begin{array}{c}\text { Facilities and } \\
\text { Infrastructure }\end{array}$ & Funding & Selection & $\begin{array}{c}\text { Training } \\
\text { Program }\end{array}$ & Evaluation \\
\hline N Valid & 85 & 85 & 85 & 85 & 85 & 85 & 85 & 85 \\
Missing & 0 & 0 & 0 & 0 & 0 & 0 & 0 & 0 \\
Mean & 40.53 & 37.38 & 20.73 & 33.96 & 38.78 & 20.62 & 58.33 & 24.28 \\
Std. Deviation & 2.343 & 2.299 & 1.795 & 2.796 & 2.994 & 1.766 & 3.721 & 2.250 \\
Variance & 5.490 & 5.285 & 3.224 & 7.820 & 8.961 & 3.118 & 13.843 & 5.062 \\
Min & 36 & 30 & 16 & 28 & 32 & 16 & 49 & 18 \\
Max & 45 & 43 & 25 & 40 & 45 & 24 & 67 & 28 \\
\hline
\end{tabular}

The statistical descriptive results in the table above regarding athlete characteristics, coach characteristics, organization, facilities and infrastructure, funding, selection, training programs, and evaluation will be described in detail as follows:

1) Characteristics of Athletes in the Development of Independent Paralympic Sports Achievements in the Preparation for the Paparnas Papua 2021

Athletes are the main resource in building achievement. The characteristics of athletes as the main resource in coaching achievements need attention because to achieve the goals of quality achievement development, standardization is needed to get prospective athletes (Cumming et al., 2008; Wigfield \& Eccles, 2002). The standardization process refers to several criteria determined by the achievement development center. To get athletes with certain criteria must go through a selection procedure. From the selection process, candidate athletes who match their talents and abilities will be obtained which can then be directed to certain sports. The characteristics of the criteria for athletes in developing paralympic sports achievements independently in the preparation for Peparnas Papua in 2021 will be explained in the table below:

Table 2

Characteristics of athletes in developing paralympic sports achievements independently in the preparation for Peparnas Papua in 2021

\begin{tabular}{llcccc}
\hline & & Frequency & Percent & Valid Percent & Cumulative Percent \\
\hline Valid & Very Poor & 10 & 11.8 & 11.8 & 11.8 \\
& Not good & 15 & 17.6 & 17.6 & 29.4 \\
& Pretty good & 27 & 31.8 & 31.8 & 61.2 \\
& Good & 25 & 29.4 & 29.4 & 90.6 \\
& Very good & 8 & 9.4 & 9.4 & 100.0 \\
& Total & 85 & 100.0 & 100.0 & \\
\hline
\end{tabular}

In the table above, it can be described that the characteristics of athletes in the development of paralympic sports achievements independently in the preparation for the Paparnas Papua in 2021 have the following results: 11.8\% have a very poor category, $17.6 \%$ have a poor category, $31.8 \%$ have a fairly good category, $29.4 \%$ have a good category, and $9.4 \%$ have a very good category. The graph of the percentage of athlete's characteristics can be seen as follows: 


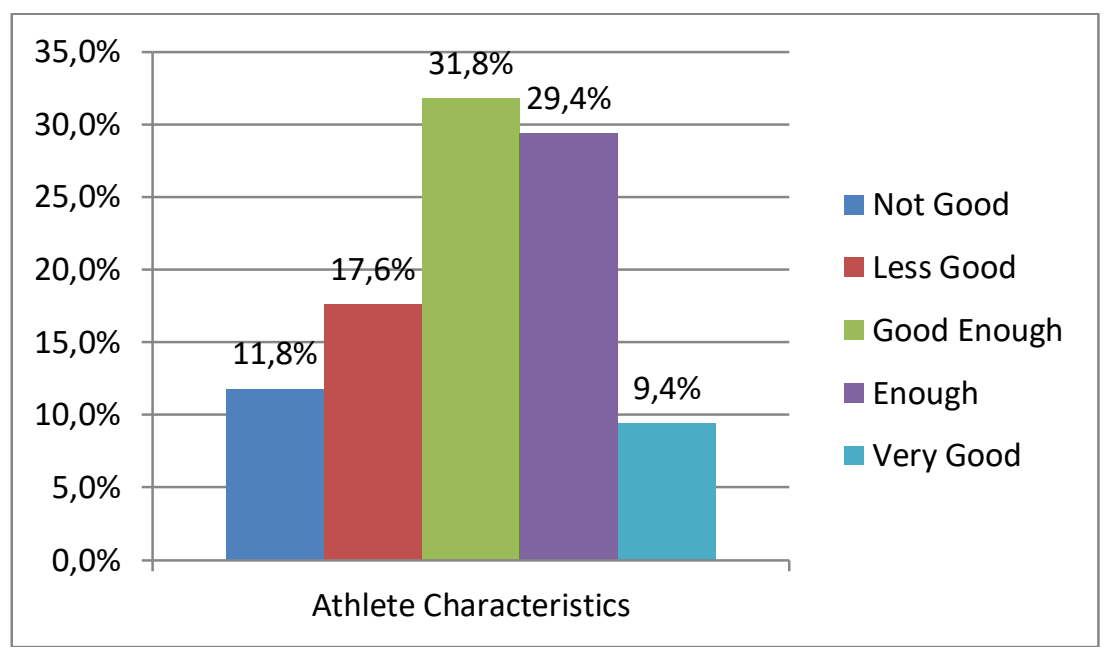

Figure 1. Graph of Athlete Characteristics

2) Characteristics of Trainers in Fostering Independent Paralympic Sports Achievements in the Preparation for Peparnas Papua in 2021

The trainer has an important role in the process of building achievement. Trainers who have good training competence and experience will have an impact on the process of achieving achievement coaching goals. The goals set by the organizers of achievement development cannot be achieved just like that, because each sport has different characteristics and challenges. So that the role of the coach in achieving the goals of achievement coaching is needed. Following are the characteristics of coaches in the development of paralympic sports achievements carried out independently in the preparation for Peparnas Papua in 2021 will be explained in the table below:

Table 3

Characteristics of coaches in developing paralympic sports achievements independently in the preparation for Peparnas Papua in 2021

\begin{tabular}{llllll}
\hline & Frequency & Percent & Valid Percent & Cumulative Percent \\
\hline Valid & Very Poor & 4 & 4.7 & 4.7 & 4.7 \\
& Not good & 12 & 14.1 & 14.1 & 18.8 \\
& Pretty good & 27 & 31.8 & 31.8 & 50.6 \\
& Good & 29 & 34.1 & 34.1 & 84.7 \\
& Very good & 13 & 15.3 & 15.3 & 100.0 \\
& Total & 85 & 100.0 & 100.0 & \\
\hline
\end{tabular}

In the table above, it can be described that the characteristics of coaches in the development of paralympic sports achievements independently in the preparation for Peparnas Papua in 2021 obtained results: $4.7 \%$ were in the very poor category, $14.1 \%$ were in the poor category, $31.8 \%$ had good enough category, $34.1 \%$ had category good, and $15.3 \%$ have a very good category. The percentage chart of athlete's characteristics can be seen as follows: 


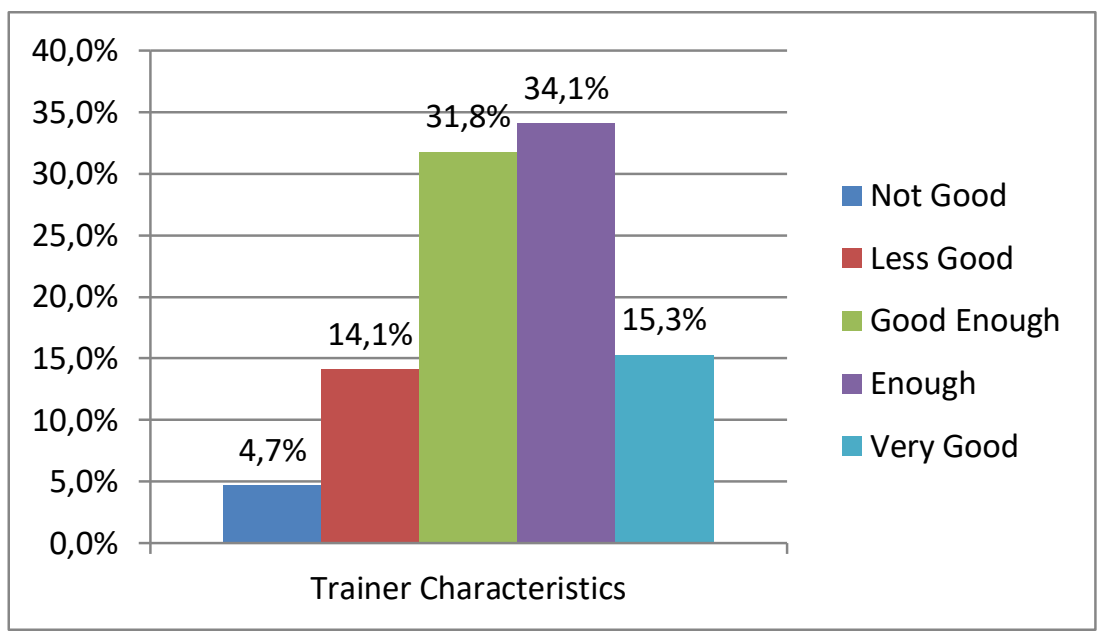

Figure 2. Graphics of trainer characteristics

3) Organizational Characteristics in Fostering Independent Paralympic Sports Achievements in the Preparation for Peparnas Papua in 2021

Organizing has a function in carrying out sports performance coaching as a system in which there is a structure of tasks carried out by each individual or group that is integrated into one common goal. The course of the process of building achievement is very dependent on the organization. If the organization in the performance building does not go well, then the goals in the achievement of achievement coaching will also be the most pressing, even not being achieved. The following is the organization of the development of paralympic sports achievements independently in the preparation for the Paparnas Papua 2021 will be explained in the table below:

Table 4

Organizational characteristics in the development of paralympic sports achievements independently at Peparnas Papua in 2021

\begin{tabular}{llllll}
\hline & Frequency & Percent & Valid Percent & Cumulative Percent \\
\hline Valid & Very Poor & 2 & 2.4 & 2.4 & 2.4 \\
& Not good & 18 & 21.2 & 21.2 & 23.5 \\
& Pretty good & 36 & 42.4 & 42.4 & 65.9 \\
Good & 23 & 27.1 & 27.1 & 92.9 \\
& Very good & 6 & 7.1 & 7.1 & 100.0 \\
Total & 85 & 100.0 & 100.0 & \\
\hline
\end{tabular}

In the table above, it can be described that the organizational characteristics of the development of paralympic sports achievements independently in the preparation for the Paparnas Papua in 2021 obtained results: $2.4 \%$ were in the very poor category, $21.2 \%$ were in the poor category, $42.4 \%$ had good enough category, $27.1 \%$ had category good, and $7.1 \%$ were in the very good category. The graph of the percentage of organizational characteristics can be seen as follows: 


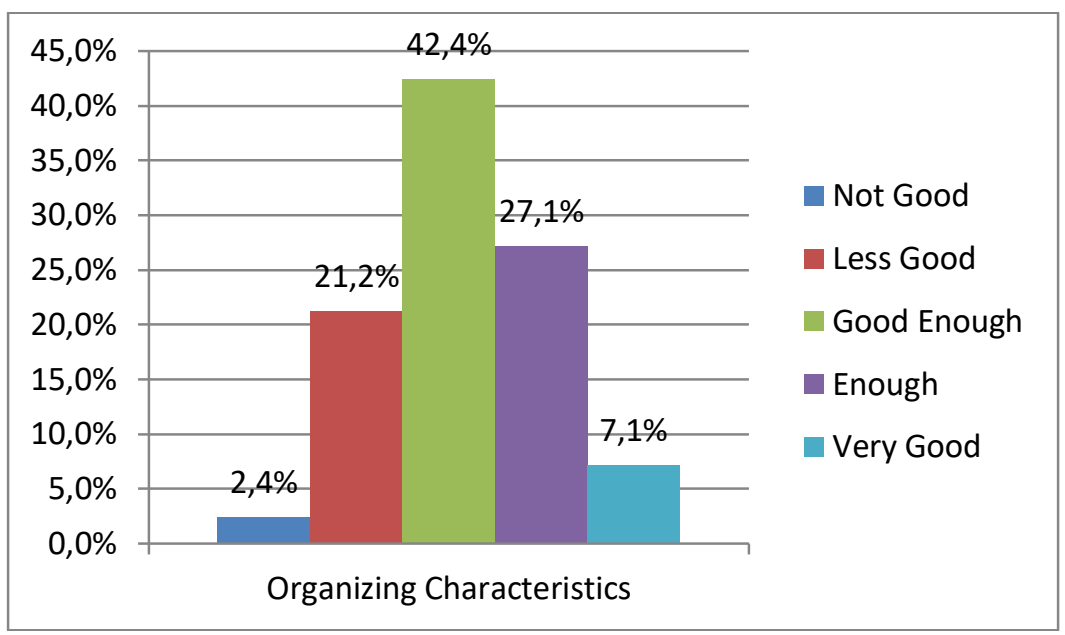

Figure 3. Graph of organizing characteristics

4) Characteristics of Facilities and Infrastructure in Fostering Independent Paralympic Sports Achievements in the Preparation for Peparnas Papua in 2021

Facilities and infrastructure are the main factors in supporting the implementation of performance development. Also, the facilities and infrastructure must meet the quality and quantity standards so that they can support the achievement of the goals of performance development. Following are the facilities and infrastructure for the development of paralympic sports achievements carried out independently in the preparation for the Paparnas Papua 2021 will be explained in the table below:

Table 5

Characteristics of facilities and infrastructure in developing paralympic sports achievements independently in preparation Peparnas Papua in 2021

\begin{tabular}{|c|c|c|c|c|c|}
\hline \multirow{7}{*}{$\overline{\text { Valid }}$} & & Frequency & Percent & Valid Percent & Cumulative Percent \\
\hline & Very Poor & 4 & 4.7 & 4.7 & 4.7 \\
\hline & Not good & 24 & 28.2 & 28.2 & 32.9 \\
\hline & Pretty good & 30 & 35.3 & 35.3 & 68.2 \\
\hline & Good & 21 & 24.7 & 24.7 & 92.9 \\
\hline & Very good & 6 & 7.1 & 7.1 & 100.0 \\
\hline & Total & 85 & 100.0 & 100.0 & \\
\hline
\end{tabular}

In the table above, it can be described that the characteristics of the facilities and infrastructure in the development of paralympic sports achievements independently in the preparation for the Paparnas Papua 2021 obtained results: 4.7\% were in the very poor category, $28.2 \%$ were in the poor category, $35.3 \%$ had good enough category, $24.7 \%$ has a good category, and $7.1 \%$ has a very good category. The percentage graph for the characteristics of facilities and infrastructure can be seen as follows: 


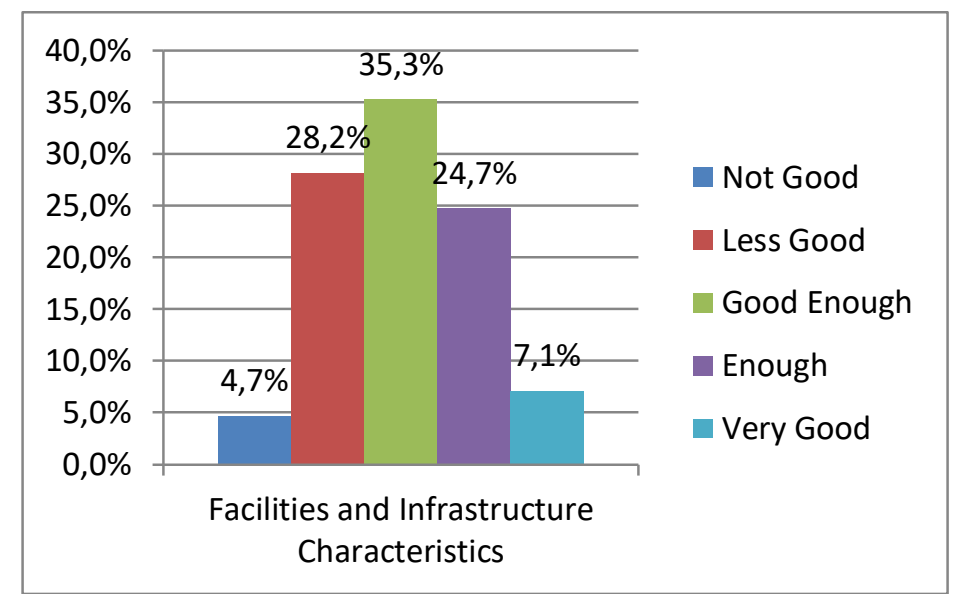

Figure 4. Graph of facilities and infrastructure characteristics

5) Funding Characteristics in the Development of Independent Paralympic Sports Achievements in the Preparation for the Papua National Peppermint for 2021

The problem most often encountered in coaching paralympic sports achievement is funding. The funding process that is hampered, reduced, or even not realized as it should be will hurt the process of developing the paralympic achievement itself. Currently, funding for the development of paralympic sports achievements comes from the government and the parent paralympic sports organizations. Also, paralympic sports, which are not as popular as sports in general, affect funding for fostering sports achievement. Following is the funding for the development of Paparnas Papua paralympic sports achievements in 2021 will be explained in the table below:

Table 6

Funding characteristics in the development of paralympic sports achievements independently in the preparation for the Papua National Education Organization in 2021

\begin{tabular}{llllll}
\hline & Frequency & Percent & Valid Percent & Cumulative Percent \\
\hline Valid & Very Poor & 10 & 11.8 & 11.8 & 11.8 \\
& Not good & 14 & 16.5 & 16.5 & 28.2 \\
& Pretty good & 37 & 43.5 & 43.5 & 71.8 \\
Good & 21 & 24.7 & 24.7 & 96.5 \\
& Very good & 3 & 3.5 & 3.5 & 100.0 \\
& Total & 85 & 100.0 & 100.0 & \\
\hline
\end{tabular}

In the table above, it can be described that the characteristics of funding in the development of paralympic sports achievements independently in the preparation for the Papua National Education Day in 2021, the results are: 11.8\% have a very poor category, $16.5 \%$ have a poor category, $43.5 \%$ have a fairly good category, $24.7 \%$ have a category good, and $3.5 \%$ were in the very good category. The graph of the percentage of funding characteristics can be seen as follows: 


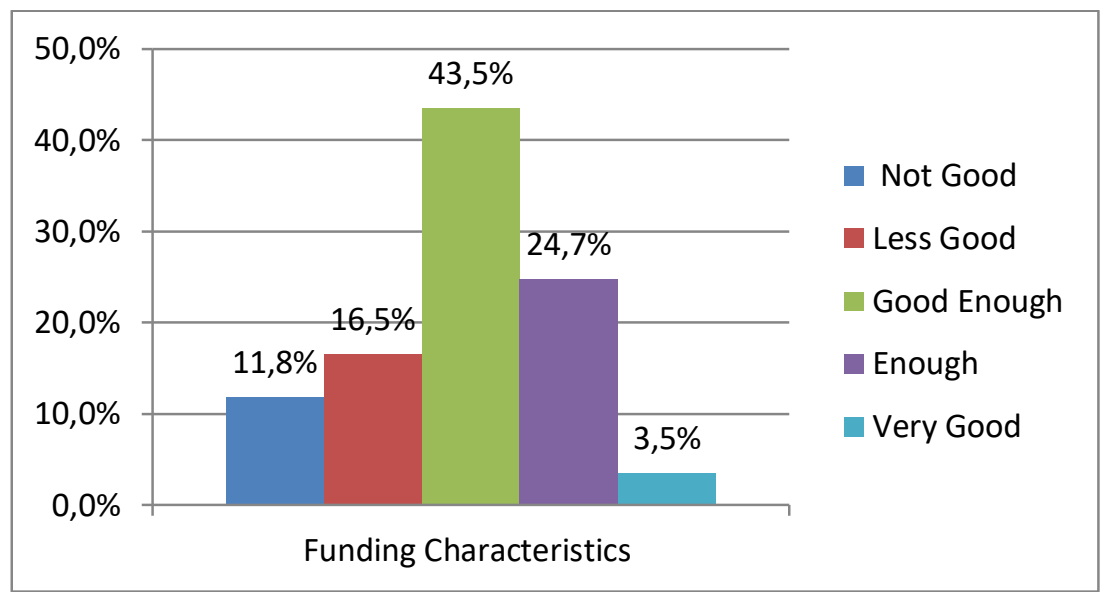

Figure 5. Funding characteristics graph

6) Characteristics of Selection in the Development of Independent Paralympic Sports Achievements in the Preparation for Peparnas Papua in 2021

The selection of paralympic sports achievement coaching is divided into two categories, namely selection for athletes and coaches. Selection is carried out using procedures that have been determined by the performance coaching organizer to find talented athletes and competent coaches. The selection procedure is carried out in several stages which will then obtain a value that will be accumulated at each stage. The results of the accumulated scores will later become a consideration for the selection committee for performance coaching to decide whether the athlete meets the standards or not. The following is the selection for the development of the Paparnas Papua paralympic sports achievements in 2021, which will be explained in the table below:

Table 7

Characteristics of selection in the development of paralympic sports achievements independently in the preparation for the Papua Peparnas in 2021

\begin{tabular}{llllll}
\hline & & Frequency & Percent & Valid Percent & Cumulative Percent \\
\hline Valid & Very Poor & 3 & 3.5 & 3.5 & 3.5 \\
& Not good & 18 & 21.2 & 21.2 & 24.7 \\
& Pretty good & 37 & 43.5 & 43.5 & 68.2 \\
& Good & 23 & 27.1 & 27.1 & 95.3 \\
& Very good & 4 & 4.7 & 4.7 & 100.0 \\
& Total & 85 & 100.0 & 100.0 & \\
\hline
\end{tabular}

In the table above, it can be described that the characteristics of the selection in the development of paralympic sports achievements independently in the preparation for the Papua National Education Day in 2021, the results are: $3.5 \%$ have a very poor category, $21.2 \%$ have a poor category, $43.5 \%$ have a fairly good category, $27.1 \%$ good, and $4.7 \%$ were in the very good category. The percentage graph of the selected characteristics can be seen as follows: 


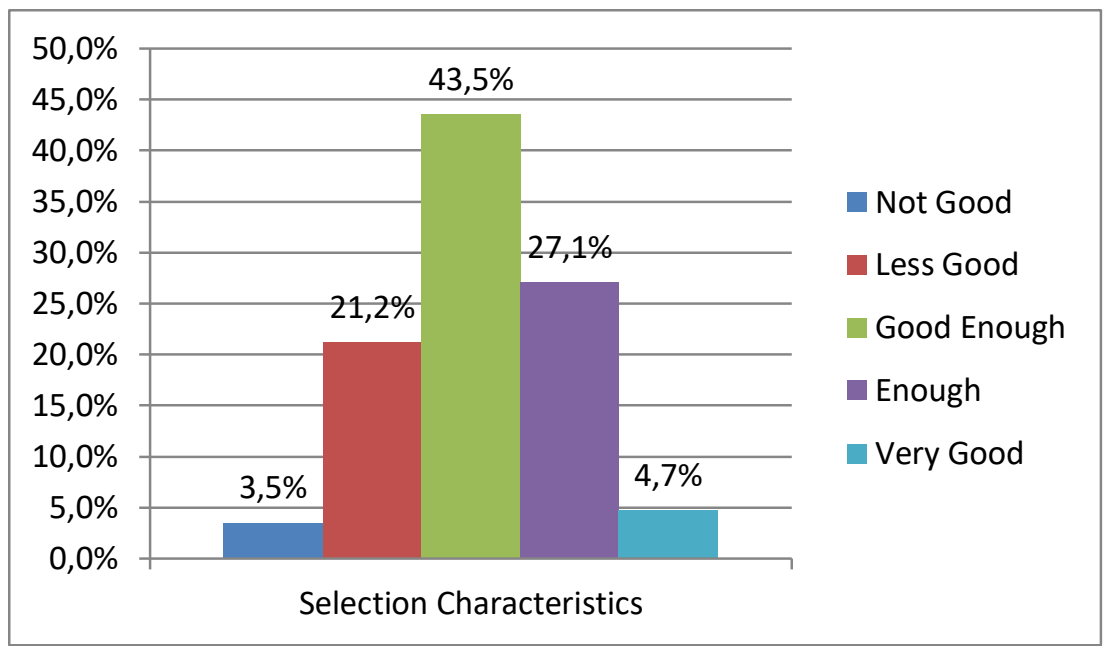

Figure 6. Graph of selection characteristics

7) Characteristics of the Training Program in the Development of Independent Paralympic Sports Achievements in the Preparation for the Paparnas Papua 2021

The success or failure of achieving the goal of coaching sports achievement cannot be separated from the training program. The training program has an important role in regulating the various training activities of athletes. Here the role of the coach is very important in designing a quality training program following the characteristics of each athlete. Training programs are tailored to target goals, namely the near, medium, and long term. The following training program on developing paralympic sports achievements independently in the preparation for Peparnas Papua in 2021 will be explained in the table below:

Table 8

Characteristics of training programs in developing paralympic sports achievements independently in the preparation for Peparnas Papua in 2021

\begin{tabular}{llllll}
\hline & Frequency & Percent & Valid Percent & Cumulative Percent \\
\hline Valid & Very Poor & 3 & 3.5 & 3.5 & 3.5 \\
& Not good & 15 & 17.6 & 17.6 & 21.2 \\
& Pretty good & 34 & 40.0 & 40.0 & 61.2 \\
& Good & 28 & 32.9 & 32.9 & 94.1 \\
& Very good & 5 & 5.9 & 5.9 & 100.0 \\
& Total & 85 & 100.0 & 100.0 & \\
\hline
\end{tabular}

In the table above, it can be described that the characteristics of the training program in the development of paralympic sports achievements independently in the preparation for the Paparnas Papua in 2021 obtained results: $3.5 \%$ had a very poor category, $17.6 \%$ had a poor category, $40 \%$ had a fairly good category, $32.9 \%$ had a good category, and $5.9 \%$ have a very good category. The graph of the percentage characteristics of the training program can be seen as follows: 


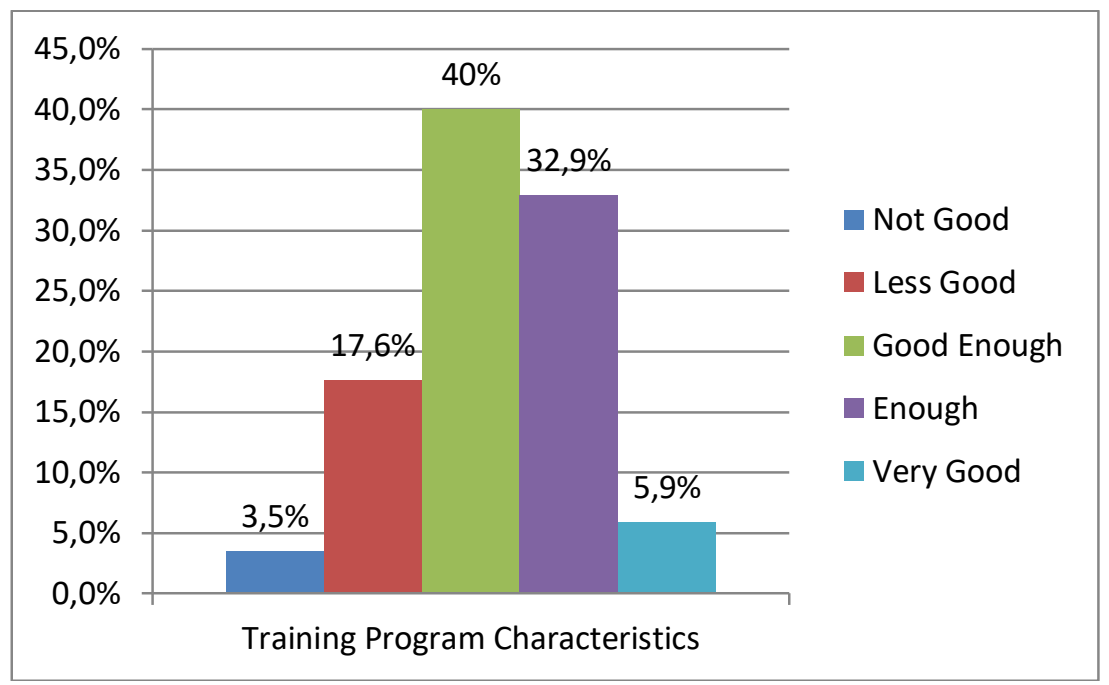

Figure 7. Graph of training program characteristics

8) Characteristics of Evaluation in the Development of Independent Paralympic Sports Achievements in the Preparation for the Papua National Education Team in 2021

The evaluation covers all aspects of training in sports achievement coaching activities. Also, the results of the matched trial can be used as evaluation material. Evaluation is carried out by the trainer to each athlete individually or in groups. Evaluation activities are carried out periodically to determine the level of success in implementing the training program (Bates, 2004; Faith, 1992). The results of the evaluation will then be used as input or improvement for further training activities. The following is an evaluation of the development of independent paralympic sports achievements in the preparation for Peparnas Papua in 2021, which will be explained in the table below:

Table 9

Characteristics of evaluation on the development of paralympic sports achievements independently at the Peparnas Papua in 2021

\begin{tabular}{llllll}
\hline & & Frequency & Percent & Valid Percent & Cumulative Percent \\
\hline Valid & Very Poor & 3 & 3.5 & 3.5 & 3.5 \\
& Not good & 17 & 20.0 & 20.0 & 23.5 \\
& Pretty good & 28 & 32.9 & 32.9 & 56.5 \\
& Good & 20 & 23.5 & 23.5 & 80.0 \\
& Very good & 17 & 20.0 & 20.0 & 100.0 \\
& Total & 85 & 100.0 & 100.0 & \\
\hline
\end{tabular}

In the table above, it can be described that the characteristics of the evaluation on the development of paralympic sports achievements independently in the preparation for the Paparnas Papua in 2021 were obtained: $3.5 \%$ had a very poor category, $20 \%$ had a poor category, $32.9 \%$ had a fairly good category, $23.5 \%$ had a category good, and $20 \%$ were in the very good category. The graph of the percentage of evaluation characteristics can be seen as follows: 


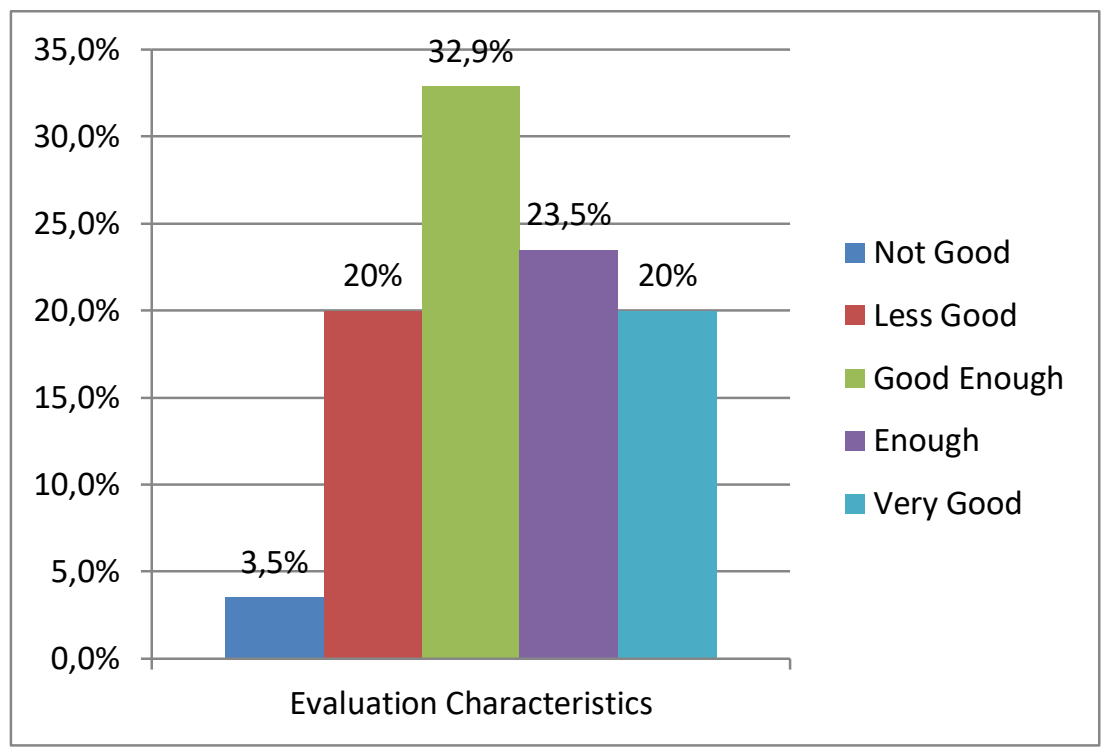

Figure 8. Graph of evaluation characteristics

\section{Conclusion}

Based on the results of the analysis of research data on the evaluation of the implementation of paralympic sports achievement coaching which was carried out independently in the preparation for the Papua National Education Day 2021, it can be concluded that the overall components of achievement development include: athletes, coaches, organizing, facilities and infrastructure, funding, selection, training programs, and the evaluation is included in the fairly good category with a questionnaire percentage value of $37.65 \%$. The results of the descriptive conclusions are as follows:

1) West Java NPCI athletes have a fairly good quality with family support, a sense of comfort being an athlete, and motivation in participating in the regional training in preparation for Paparnas Papua in 2021.

2) Trainers at NPCI West Java have qualifications as trainers such as: trainer license, training experience, and a competent trainer recruitment system. The West Java NPCI trainer has carried out the coaching process well.

3) The organization of the West Java NPCI has been carried out quite well through the implementation of tasks given by the organization, the division of workgroups within the organization, and the commitment of the institutions or members together to support the achievement of goals in implementing the regional plates.

4) The facilities and infrastructure in supporting the implementation of the NPCI West Java platda have quite good criteria with the feasibility of facilities and infrastructure standards, support for communication tools, and the suitability of the training ground used by athletes in implementing the regional training plate.

5) The funding of the West Java NPCI platda is already in the quite good category with funding sources, salary issues for athletes and coaches, and intensive bonuses for athletes and coaches that are managed and optimized to support the achievement of optimal achievements in the preparation for Paparnas Papua in 2021.

6) The selection of West Java NPCI athletes has been carried out quite well using several criteria such as: the age of the recruited athletes, the physical condition of the athletes, and the selection process for athletes to find quality athletes to support the human resources of athletes who will be prepared for long-term coaching.

7) The West Java NPCI training program is currently being carried out quite well through the suitability of the planning program with the implementation and the suitability of independent training with the program carried out by athletes in the implementation of Papuas Peparnas in 2021.

The evaluation of the West Java NPCI platda is carried out by the trainer at the end of each training or after the training and runs smoothly. Evaluation administration in training is still carried out by simply taking notes and the results of the evaluation are used by the trainer as a guide and input in formulating the next training program. 
Acknowledgments

I thank to My almamater Sebelas Maret University, Slamet Riyadi. As the head of the sports science study program, M. Furqon Hidayatullah and Sapta Kunta Purnama. As a lecturer who has given good advice and guidance.

\section{References}

Bates, R. (2004). A critical analysis of evaluation practice: the Kirkpatrick model and the principle of beneficence. Evaluation and program 341-347. https://doi.org/10.1016/j.evalprogplan.2004.04.011

Batitusta, M. R., \& Supriyono, S. (2019). A Employment Development Survey of NPC Swimming Atlets in Surakarta 2018. ACTIVE: Journal of Physical Education, Sport, Health and Recreation, 8(1), 22-26.

Batitusta, M. R., \& Supriyono, S. (2019). A Employment Development Survey of NPC Swimming Atlets in Surakarta 2018. ACTIVE: Journal of Physical Education, Sport, Health and Recreation, 8(1), 22-26.

Beckman, E. M., Connick, M. J., \& Tweedy, S. M. (2017). Assessing muscle strength for the purpose of classification in Paralympic sport: A review and recommendations. Journal of Science and Medicine in Sport, 20(4), 391-396. https://doi.org/10.1016/j.jsams.2016.08.010

Blauwet, C., \& Willick, S. E. (2012). The Paralympic Movement: using sports to promote health, disability rights, and social integration for athletes with disabilities. $P M \& R, 4(11)$, 851-856. https://doi.org/10.1016/j.pmrj.2012.08.015

Brittain, I. (2012). The Paralympic Games: from a rehabilitation exercise to elite sport (and back again?). International Journal of Therapy and Rehabilitation, 19(9), 526-530.

Budi, B., \& Lismadiana, L. (2020). Evaluasi Program Pembinaan Atletik di Pengcab PASI Kabupaten Kuningan. JUARA: Jurnal Olahraga, 5(2), 209-221.

Cumming, S. P., Smith, R. E., Smoll, F. L., Standage, M., \& Grossbard, J. R. (2008). Development and validation of the achievement goal scale for youth sports. Psychology of Sport and Exercise, 9(5), 686-703. https://doi.org/10.1016/j.psychsport.2007.09.003

Dieffenbach, K. D., \& Statler, T. A. (2012). More similar than different: The psychological environment of Paralympic sport. Journal of Sport Psychology in Action, 3(2), 109-118.

Faith, D. P. (1992). Conservation evaluation and phylogenetic diversity. Biological conservation, 61(1), 1-10. https://doi.org/10.1016/0006-3207(92)91201-3

Imanudin, I. (2011). Analisa Prestasi Hasil Tolakan Pada Cabang Olahraga Atletik Nomor Tolak Peluru. Jurnal Kepelatihan Olahraga, 1(2), 18-24.

Jaarsma, E. A., Geertzen, J. H., de Jong, R., Dijkstra, P. U., \& Dekker, R. (2014). Barriers and facilitators of sports in Dutch Paralympic athletes: An explorative study. Scandinavian journal of medicine \& science in sports, 24(5), 830-836.

Kardiyanto, D. W., Setijono, H., \& Mintarto, E. (2017). The Evaluation Of Indonesia Paralympic Coaching. European Journal of Special Education Research.

Kliwon, K., \& Sarwanto, A. (2019). Pengaruh Aktivasi Regulasi Emosi Terhadap Prestasi Olahraga Atlet Disabilitas NPC Kota Surakarta. Interest: Jurnal Ilmu Kesehatan, 8(2), 177-183.

Nakamura, S., Wada, K., Yanagisawa, N., \& Smith, D. R. (2018). Health risks and precautions for visitors to the Tokyo 2020 Olympic and Paralympic Games. Travel medicine and infectious disease, 22, 3-7. https://doi.org/10.1016/j.tmaid.2018.01.005

Ona Ayala, K. E., Li, X., Huang, P., Derman, W. E., Kissick, J., Webborn, N., ... \& Tuakli-Wosornu, Y. A. (2019). Injury epidemiology and preparedness in powerlifting at the Rio 2016 Paralympic Games: An analysis of 1410 athlete-days. Translational Sports Medicine, 2(6), 358-369.

Pullen, E., \& Silk, M. (2020). Disability, Masculinity, Militarism: The Paralympics and the Cultural (Re-) production of the Para-athlete-soldier. Journal of War \& Culture Studies, 13(4), 444-461.

Putra, M. F. P., \& Ita, S. (2019). Gambaran kapasitas fisik atlet Papua: Kajian menuju PON XX Papua. Jurnal Keolahragaan, 7(2), 135-145.

Rahmat, Z. (2015). Atletik Dasar dan Lanjutan. Atletik Dasar dan Lanjutan.

Singh, A., \& Parmar, D. S. (2016). A comparative study of psychological factor among female athletes. International research journal of engineering, IT \& scientific research, 2(1), 8-21.

Wigfield, A., \& Eccles, J. S. (2002). The development of competence beliefs, expectancies for success, and achievement values from childhood through adolescence. In Development of achievement motivation (pp. 91120). Academic Press. https://doi.org/10.1016/B978-012750053-9/50006-1 
Wijayanti, D. G. S., Soegiyanto, S., \& Nasuka, N. (2016). Pembinaan Olahraga Untuk Penyandang Disabilitas Di National Paralympic Committee Salatiga. Journal of Physical Education and Sports, 5(1), 17-23.

Zuhriyah, A., Kristiyanto, A., \& Purnama, S. K. (2020). Management of National Paralympic Committee Indonesia (Npci) Of High-Performance Sport In Klaten Regency. International Journal of Psychosocial Rehabilitation. 